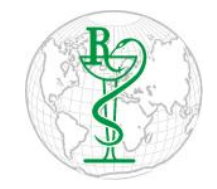

INDO GLOBAL JOURNAL OF

PHARMACEUTICAL SCIENCES

ISSN 2249- 1023

\title{
UV-Spectrophotometric Estimation and Forced Degradation Studies of Tenofovir Alafenamide Fumarate (TAF) in its Bulk and Tablet Dosage Form
}

\author{
K. Bhavyasri ${ }^{1 *}$, M. Manisha ${ }^{1}$, D. Rambabu ${ }^{2}$ \\ ${ }^{1}$ Department of Pharmaceutical Analysis, RBVRR Women's College Of Pharmacy, Barkatpura, Hyderabad, Telangana-500027, India. \\ ${ }^{2}$ Gland Pharma Pvt Ltd, Hyderabad, Telangana, India
}

Address for Correspondence: K. Bhavyasri, bhavya.khagga@gmail.com

\begin{abstract}
Received:
01.06.2019

Accepted:

10.03.2020

Published:

15.12 .2020

Keywords

Tenofovir

Alafenamide

Fumarate; UV-

Visible

spectrometer;

Forced

degradation

studies; Stress

conditions.
\end{abstract}

\begin{abstract}
A simple, sensitive and reproducible Spectrophotometric method is developed for estimation of Tenofovir Alafenamide Fumarate (TAF) in bulk and its tablet dosage form. Forced degradation studies are also conducted on standard TAF and \% degradation of drug under various stress conditions is reported. Different concentrations of TAF are prepared using distilled water: acetonitrile as diluent. The absorption maximum of TAF is found to be at $261 \mathrm{~nm}$. Linearity was established in the range of $6.25-37.5 \mu \mathrm{g} / \mathrm{ml}$ with regression coefficient of 0.999 . The drug was subjected to acid and alkali hydrolysis, oxidation degradation, thermal and photo degradation conditions. () 2020 iGlobal Research and Publishing Foundation. All rights reserved.
\end{abstract}

Cite this article as: Bhavyasri, K.; Manisha, M.; Rambabu, D. UV-spectrophotometric estimation and forced degradation studies of tenofovir alafenamide fumarate (TAF) in its bulk and tablet dosage form. Indo Global J. Pharm. Sci., 2020; 10(4): 1-5. DOI: http://doi.org/10.35652/IGJPS.2020.10401 .

\section{INTRODUCTION}

Tenofovir Alafenamide Fumarate (TAF), (E)-but-2-enedioic acid; propan-2-yl (2S)-2-[[(2R)-1-(6-aminopurin-9-yl) propan2-yl] oxymethyl phenoxyphosphoryl] amino] propionate is an antiretroviral drug which is used in treatment of chronic Hepatitis B and HIV/AIDS infection. [1-2]. It is nucleotide reverse transcriptase inhibitor. Tenofovir Alafenamide Fumarate (Fig. 1) is a Fumarate salt prepared from Tenofovir Alafenamide by reaction of one molecule of fumaric acid for every two molecules of Tenofovir Alafenamide, a prodrug for Tenofovir; it is used in combination therapy for the treatment of HIV-1 infection. It has a role as an antiviral drug, a HIV-1 reverse transcriptase inhibitor and a prodrug.

A literature survey has revealed that only two articles on UV spectroscopic assay of TAF are reported. A few methods in literature review are found for determination of TAF in combined dosage forms and include High Pressure Liquid
Chromatography (HPLC)[1-3].A method based on the measurement absorbance of the drug in water at $260 \mathrm{~nm}$ has been reported and the method obeys Beer's law in the 2-10 $\mu \mathrm{g} / \mathrm{ml}$ concentration range [7].<smiles>CC(C)OC(=O)[C@H](C)NP(=O)(COC(C)Cn1cnc2c(N)ncnc21)Oc1ccccc1</smiles>

Fig. 1 Structure of TAF 


\section{Indo Global Journal of Pharmaceutical Sciences, 2020; 10(4): 1-5}

Simultaneous estimation of TAF and Emtricitabine by UV spectroscopic method is found in a literature. The method involving determination of TAF and Emtricitabine at $260 \mathrm{~nm}$ and $280 \mathrm{~nm}$ over the concentration ranges of $5-30 \mu \mathrm{g} / \mathrm{ml}$ for both drugs has been described [6].

Most of the reported methods are often time consuming, expensive, use multi or expensive reagents, cumbersome and required expertise operational personnel. UV spectrophotometry, because of simplicity, reproducibility and speed and also it requires minimum solvent/reagent system and less analysis time, is widely used for the assay of the therapeutic compounds used as medications.

\section{MATERIALS AND METHODS}

\section{Apparatus}

The Spectrophotometric measurements were carried out using Elico SL 210 UV/Visible spectrophotometer.

\section{Materials}

All chemicals used were of reagent grade. Distilled water was used to prepare solutions wherever required. Acetonitrile, hydrogen peroxide ( $\mathrm{H} 2 \mathrm{O} 2)$, hydrochloric acid and sodium hydroxide were purchased from Merck (Mumbai, India). Tenofovir Alafenamide Fumarate sample (purity99.5\%) was kindly supplied by Mylan laboratories, Hyderabad, India. Commercial brand of tablets namely HepBest (Mylan Pharmaceuticals Ltd., Indore, India) were purchased from local commercial sources.

\section{Reagents}

Hydrochloric acid (1 M) was prepared by appropriate dilution of concentrated acid with water. A $5 \%$ solution of $\mathrm{H} 2 \mathrm{O} 2$ was prepared by diluting suitable volume of the commercially available reagent to $100 \mathrm{ml}$ with water in a volumetric flask. Sodium hydroxide solution (1M) was prepared by dissolving required amount of the pellets in water.

\section{Selection of Diluent}

The solvent was selected by determining the solubility of Tenofovir Alafenamide Fumarate in various solvents namely Distilled water, Hydrochloric Acid, Sodium Hydroxide Solution, Methanol. Finally, acetonitrile: Distilled water (20:80) was chosen as the solvent for Tenofovir Alafenamide Fumarate depending on absorption at its analytical wavelength.

\section{Standard Drug Solution}

Preparation of stock solution $(250 \mu \mathrm{g} / \mathrm{ml})$ : weigh about $25 \mathrm{mg}$ of Tenofovir Alafenamide Fumarate and transfer to $25 \mathrm{ml}$ volumetric flask, dissolve it in diluent and make up the final volume to $25 \mathrm{ml}$ with diluent.

\section{Procedures}

Preparation of calibration curve

Into a series of $10 \mathrm{ml}$ calibration flasks, aliquots of standard drug solution $(0.25-1.25 \mathrm{ml}$ of $250 \mu \mathrm{g} / \mathrm{ml})$ equivalent to 6.25 $37.5 \mu \mathrm{g} / \mathrm{ml}$ TAF were accurately transferred and the volume was made up to the mark with the diluent. The absorbance of each solution was then measured at $261 \mathrm{~nm}$ against the respective diluent. Calibration curve was prepared by plotting the absorbance versus concentration of drug. The concentration of the unknown was read from the respective calibration curve or computed from the regression equation derived using the Beer's law data.

\section{Analysis of tablets}

Twenty tablets from commercial brand (HepBest) were weighed and crushed into a fine powder using a Pestle and Mortar. An amount of tablet powder equivalent to $10 \mathrm{mg}$ of TAF was transferred into a $100 \mathrm{ml}$ volumetric flask. The content was shaken well with about $50 \mathrm{ml}$ of the respective diluent for $20 \mathrm{~min}$. The mixture was diluted to the mark with the same diluent. It was filtered using Whatmann No 42 filter paper. First $10 \mathrm{ml}$ portion of the filtrate was discarded and a subsequent portion was diluted to get a working concentration and subjected to analysis following the procedures described earlier.

\section{Forced degradation study}

A $1 \mathrm{ml}$ aliquot of the standard $25 \mu \mathrm{g} / \mathrm{ml}$ TAF was taken (in triplicate) in a $10 \mathrm{ml}$ volumetric flask and mixed with $5 \mathrm{ml}$ of $1 \mathrm{M} \mathrm{HCl}$ (acid hydrolysis) or $1 \mathrm{M} \mathrm{NaOH}$ (alkaline hydrolysis) and boiled for $2 \mathrm{~h}$ at $400 \mathrm{C}$ on a hot water bath or $3 \% \mathrm{H} 2 \mathrm{O} 2$ (oxidative degradation) at room temperature for $2 \mathrm{~h}$. The solution was cooled to room temperature, neutralized and diluted to the mark with diluent. In thermal degradation, solid drug was kept in Petri dish in an oven at 400Cfor $2 \mathrm{~h}$. After cooling to room temperature, $10 \mathrm{mg}$ of TAF was weighed and transferred to a $100 \mathrm{ml}$ volumetric flask, dissolved in and diluted up to the mark with the respective diluent. For UV degradation study, suitable aliquot of the stock solution $(250 \mu \mathrm{g} / \mathrm{ml})$ was exposed to UV radiation for $4 \mathrm{~h}$ in a UV chamber. Finally, the absorbance of all the resulting solutions $(25 \mu \mathrm{g} / \mathrm{ml})$ obtained from acid and alkaline hydrolysis, oxidative degradation, thermal and UV degradation of TAF was measured at $261 \mathrm{~nm}$ against the respective solvent as blank in each case. [16-20]. 


\section{Indo Global Journal of Pharmaceutical Sciences, 2020; 10(4): 1-5}

\section{RESULTS AND DISCUSSION}

\section{Spectral characteristics}

The standard test solution $(25 \mu \mathrm{g} / \mathrm{ml})$ in acetonitrile: distilled water (20:80) showed absorption maximum at $261 \mathrm{~nm}$. The spectrum thus obtained is shown in Fig. 2.

Table 1. Regression and analytical parameters

\begin{tabular}{|c|c|}
\hline Parameter & Method \\
\hline$\lambda_{\max }, \mathrm{nm}$ & 261 \\
\hline Beer's law limit & $\begin{array}{c}6.25-37.5 \\
\mu \mathrm{g} / \mathrm{ml}\end{array}$ \\
\hline Molar absorptivity $(\mathrm{L} / \mathrm{mol} / \mathrm{cm})$ & $2.80 \times 10^{7}$ \\
\hline Limit of detection, $\mu \mathrm{g} / \mathrm{ml}$ & 0.331 \\
\hline Limit of quantification, $\mu \mathrm{g} / \mathrm{ml}$ & 1.002 \\
\hline \multicolumn{2}{|l|}{ Regression equation, $\mathrm{Y}^{*}$} \\
\hline Intercept (a) & -0.008 \\
\hline Slope (b) & 0.026 \\
\hline Correlation coefficient $(\mathrm{r})$ & 0.999 \\
\hline \multicolumn{2}{|c|}{$\begin{array}{c}* Y=a+b X \text {, where } Y \text { is the absorbance, } a \text { is the } \\
\text { intercept, } b \text { is the slope and } X \text { is the concentration in } \\
\mu \mathrm{g} / \mathrm{ml}\end{array}$} \\
\hline
\end{tabular}

Fig. 2 Spectrum of TAF in diluent

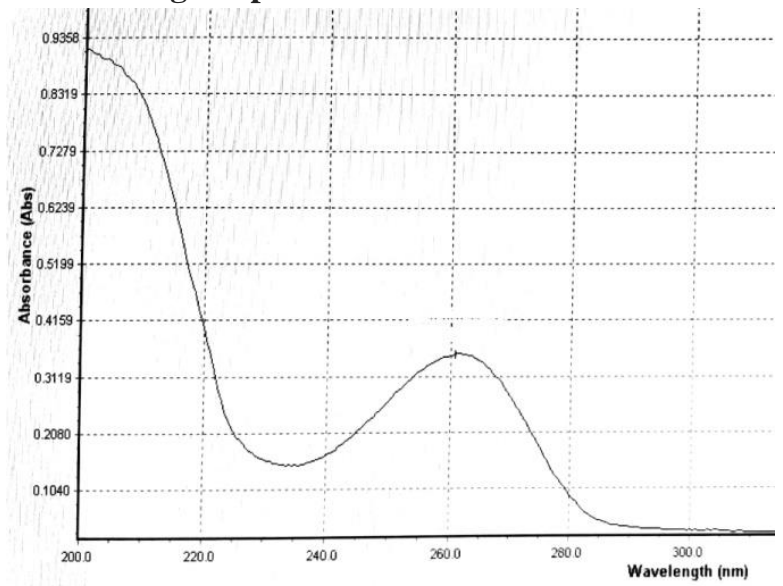

Method validation

Linearity, sensitivity, limits of detection and quantification

A linear correlation was found between absorbance at $\lambda \max$ and concentration of TAF. The graphs are described by the regression equation: $\mathrm{Y}=\mathrm{a}+\mathrm{bX}$ (where $\mathrm{Y}=$ absorbance of drug solution; $\mathrm{a}=$ intercept; $\mathrm{b}=$ slope and $\mathrm{X}=$ concentration of drug in $25 \mu \mathrm{g} / \mathrm{ml}$ ). The slope (b), intercept (a) and correlation coefficient (r) for each system were evaluated by using the method of least squares Optical characteristics such as Beer's law limits, molar absorptivity (ICH-Q1A (R2)) of the method are calculated. The limit of detection (LOD) and limit of quantitation (LOQ) are also calculated and all these data are presented in Table 1. High values of molar absorptivity (e), low values LOD revealed that, the proposed method are highly sensitive. A plot was constructed by concentration on $\mathrm{x}$-axis and absorbance on y-axis. The correlation coefficient ( $r$ ) was found to be 0.999 and the summary of study is given in Table $\mathbf{2}$ and graph is represented as Fig. 3.

\section{Precision and accuracy}

To check the repeatability and reproducibility of the proposed methods, the standard drug solution of three different concentrations were scanned, each concentration six times within the day (intra-day precision, $\mathrm{n}=6$ ) and six times on two different days (inter-day precision, $\mathrm{n}=6$ ). System precision and method precision were also performed using $25 \mu \mathrm{g} / \mathrm{ml}$ standard drug solution $(n=6)$. The percentage relative standard deviation (\%RSD) values were within limit indicating high precision of the method, summarized in Table 3. The accuracy of the methods was evaluated by standard addition method. A known concentration standard drug solution was spiked to known concentration of sample solution in three levels and \%recovery is calculated. The results of this study are summarized in Table 4

\section{Ruggedness and robustness}

The robustness of the methods was evaluated by measuring the absorbance at different wavelengths whereas the method ruggedness was performed by two different analysts. Intermediate precision values (\% RSD) are presented in Table 3.

Table 2. Calibration data

\begin{tabular}{|c|c|}
\hline Concentration $(\boldsymbol{\mu g} / \mathbf{m l})$ & Absorbance \\
\hline 0 & 0 \\
\hline 6.25 & 0.151 \\
\hline 12.5 & 0.327 \\
\hline 18.75 & 0.473 \\
\hline 25 & 0.654 \\
\hline 31.25 & 0.809 \\
\hline 37.5 & 0.992 \\
\hline
\end{tabular}

Fig. 3 Calibration curve

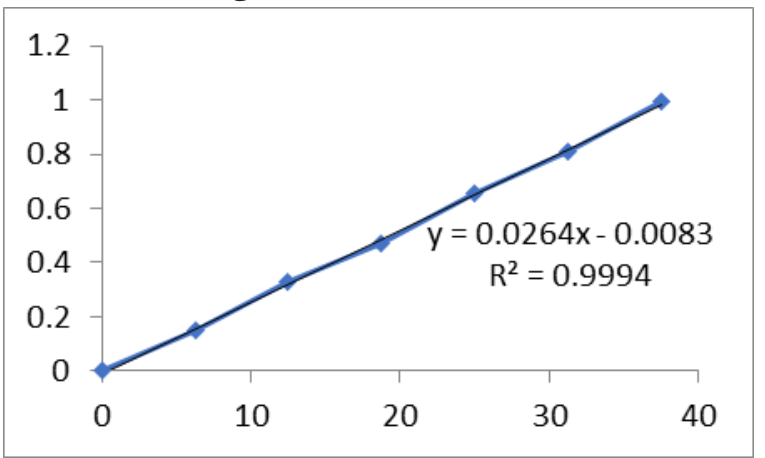




\section{Indo Global Journal of Pharmaceutical Sciences, 2020; 10(4): 1-5}

\section{Analysis of tablets}

Commercial TAF tablets were analyzed using developed method and \% assay was calculated which was found to be to $100.10 \%$ using following equation:

$$
\% \text { assay }=\frac{A(\text { sample })}{A(\text { std })} \times \frac{C(\text { std })}{C(\text { sample })} \times 100
$$

Where, $\mathrm{A}$ is absorbance and $\mathrm{C}$ is concentration

Table 3. Results of precision, robustness and ruggedness

\begin{tabular}{|c|c|}
\hline Parameter & $\%$ RSD \\
\hline \multicolumn{2}{|l|}{ PRECISION } \\
\hline System precision & $0.397 \%$ \\
\hline Method precision & $0.508 \%$ \\
\hline \multirow[t]{3}{*}{ Intra-day $(n=6)$} & $0.71 \%(12.5 \mu \mathrm{g} / \mathrm{ml})$ \\
\hline & $0.40 \%(25 \mu \mathrm{g} / \mathrm{ml})$ \\
\hline & $0.52 \%(37.5 \mu \mathrm{g} / \mathrm{ml})$ \\
\hline \multirow[t]{3}{*}{ Inter-day $(n=6)$} & $0.87 \%(12.5 \mu \mathrm{g} / \mathrm{ml})$ \\
\hline & $0.68 \%(25 \mu \mathrm{g} / \mathrm{ml})$ \\
\hline & $0.44 \%(37.5 \mu \mathrm{g} / \mathrm{ml})$ \\
\hline \multicolumn{2}{|l|}{ ROBUSTNESS } \\
\hline At 259nm & $0.92 \%$ \\
\hline At $263 \mathrm{~nm}$ & $0.86 \%$ \\
\hline \multicolumn{2}{|l|}{ RUGGEDNESS } \\
\hline Analyst-1 & $0.39 \%$ \\
\hline Analyst-2 & $0.43 \%$ \\
\hline
\end{tabular}

\section{Force degradation study}

The stress studies of the drug were carried out by subjecting TAF to acid and alkali hydrolysis, dry heat treatment, UVdegradation and hydrogen peroxide oxidation and later absorption spectra were recorded. The comparison of the absorbance of stressed TAF samples with that of the standard TAF solution showed that TAF has undergone degradation under all stress condition and a summary is given in Table 5.

Table 4. Accuracy results and \% recovery

\begin{tabular}{|c|c|c|c|c|}
\hline $\begin{array}{c}\text { Lev } \\
\text { el }\end{array}$ & $\begin{array}{c}\text { Standard } \\
\text { concentration( } \\
\boldsymbol{\mu g} / \mathbf{m l})\end{array}$ & $\begin{array}{c}\text { Sample } \\
\text { concentration( } \\
\boldsymbol{\mu g} / \mathbf{m l})\end{array}$ & $\begin{array}{c}\text { \% recov } \\
\text { ery }\end{array}$ & $\begin{array}{c}\text { \% R } \\
\text { SD }\end{array}$ \\
\hline \multirow{3}{*}{50} & 5 & 10 & 101.88 & \\
\cline { 2 - 4 }$\%$ & 5 & 10 & 97.95 & \multirow{2}{*}{0.53} \\
\hline \multirow{3}{*}{100} & 5 & 10 & 99.52 & $\%$ \\
\cline { 2 - 4 }$\%$ & 10 & 10 & 99.35 & \\
\cline { 2 - 4 } & 10 & 10 & 98.73 & \multirow{2}{*}{0.42} \\
\cline { 2 - 4 } 150 & 10 & 10 & 100.68 & $\%$ \\
\cline { 2 - 4 }$\%$ & 15 & 10 & 98.19 & \multirow{2}{*}{0.19} \\
\hline
\end{tabular}

Table 5. Summary of force degradation study.

\begin{tabular}{|c|c|c|c|}
\hline $\begin{array}{c}\text { Degradation } \\
\text { condition }\end{array}$ & Time & Absorbance & $\begin{array}{c}\% \\
\text { degradation }\end{array}$ \\
\hline $\begin{array}{c}\text { Acid }(1 \mathrm{M} \mathrm{HCl}) \\
\text { at } 40^{\circ} \mathrm{C}\end{array}$ & $2 \mathrm{~h}$ & 0.566 & 14.88 \\
\hline $\begin{array}{c}\text { Base }(1 \mathrm{M} \\
\mathrm{NaOH}) \text { at } 40^{\circ} \mathrm{C}\end{array}$ & $2 \mathrm{~h}$ & 0.583 & 12.06 \\
\hline $3 \% \mathrm{H}_{2} \mathrm{O}_{2}$ at $\mathrm{RT}^{*}$ & $2 \mathrm{~h}$ & 0.493 & 25.86 \\
\hline $\begin{array}{c}\text { Thermal at } 40 \\
{ }^{0} \mathrm{C}\end{array}$ & $2 \mathrm{~h}$ & 0.560 & 15.27 \\
\hline In UV chamber & $4 \mathrm{~h}$ & 0.529 & 19.97 \\
\hline$* R T$ means room temperature \\
\hline
\end{tabular}

\section{CONCLUSION}

In this study, the degradation behavior of TAF was studied by subjecting the drug to various stress conditions recommended by ICH. The additional findings in this study show that the drug undergoes an extensive degradation under oxidative (peroxide) condition. The method was validated for parameters like linearity, precision, accuracy, ruggedness and robustness. Application of this method for the analysis of TAF tablet dosage forms showed that there was no interference of excipients in the determination. The method is advantageous over most of the reported methods in-terms of sensitivity, simplicity, cost-effectiveness and experimental conditions. The method does not involve any tedious procedural steps; do not require any extra reagents or longer analysis time and a very simple instrument is required. The method can be used to determine the purity of the drug available from various sources.

\section{ACKNOWLEDGEMENT}

We are thankful to Mylan Pharmaceutical Ltd., Hyderabad (India) for providing gift sample of TAF for our research article.

\section{DATA AVAILABILITY}

Not declared.

\section{CONFLICTS OF INTEREST}

The authors declare no conflict of interest in this research article.

\section{FUNDING SOURCE}

No external funding declared.

\section{REFERENCES}

1. Mastanamma S, Jyothi JA, Saidulu P, Varalakshmi M. Development and Validation of RP-HPLC Method for the Simultaneous Estimation of Lamivudine, Tenofovir 


\section{Indo Global Journal of Pharmaceutical Sciences, 2020; 10(4): 1-5}

Alafenamide and Dolutegravir Bulk and their Combined Dosage Form. Pharmaceutical Methods. 2018 Jul 1; 9(2).

2. Akram NM, Umamahesh M. A New Validated RP-HPLC Method for the Determination of Lumacaftor and Ivacaftor in its Bulk and Pharmaceutical Dosage Forms. Orient J Chem. 2017 Jan 1; 33(3):1492-501.

3. Kavitha KY, Geetha G, Hariprasad R, Venkatnarayana R, Subramanian G. Development and validation of RP-HPLC analytical method for simultaneous estimation of Emtricitabine, Rilpivirine, Tenofovir Disoproxil Fumarate and Its pharmaceutical dosage forms. Pharmacie Globale. 20134(1):1.

4. Mastanamma K, Venkata Reddy D, Saidulu P, Varalakhim Method Development and validation of stability indicating RPHPLC method for the simultaneous estimation of emtricitabine tenofovir alafenamide bulk and their combined dosage form. Journal of chemical and Pharmaceutical Research. 2017;9(9):7080.

5. Shymala M. Analytical method validation for essay of emitricitabine, rilpevirene and tenofovir alfanamide by RPHPLC. Int. J. Med. Pharm. Res., 2018, 6 (3): 94.; 100.

6. Shelke A, Shinde M, Mogal R, Sable R, Jadhav A. Application of UV Spectrophotometric methods for simultaneous estimation of Emtricitabine and Tenofovir alafenamide fumarate in bulk. Asian Journal of Pharmacy and Technology. 2018 Jun 1; 8(2).

7. Kumar P, Jacob J, Ajina K. Spectroscopic Estimation of Tenofovir Alafenamide, an antiretroviral drug. Research Journal of Pharmacy and Technology. 2016 May 1; 9(5):538.

8. Singh S, Junwal M, Modhe G, Tiwari H, Kurmi M, Parashar N, Sidduri P. Forced degradation studies to assess the stability of drugs and products. Trends in Analytical Chemistry. 2013 Sep 1; 49:71-88.

9. P. D. Sethi.Sethi PD. HPLC: High Performance Liquid Chromatography: Quantitative Analysis of Pharmaceutical Formulations. CBS Publishers \& Distributors.; 2001.

10. Osselton MD, Watts J. Clarke's analysis of drugs and poisons. Moffat AC, Widdop B, editors. London: Pharmaceutical press; 2011.

11. Ahsan ML, Ali A, Ahmed I. Analytical methods for solving the sustainability problem: An aerial perspective. European Journal of Advanced Chemistry. 2010; 1(4):1-2.

12. Balaji M, Reddy IS, Kumar VA, Ulaganathan C, Muneer S. Method Development and Validation of HPTLC Method For Quantitative Estimation of Tenofovir

13. Matta MK, Burugula L, Pilli NR, Inamadugu JK, Jvln SR. A novel LC-MS/MS method for simultaneous quantification of tenofovir and lamivudine in human plasma and its application to a pharmacokinetic study. Biomedical Chromatography.2012, Oct; 26(10):1202-9.

14. Chandra P, Rathore AS, Sathiyanarayanan 1, Mahadik KR. Application of highperformance thin-layer chromatographic method for the simultaneous determination of lamivudine and tenofovir Disoproxil Fumarate in Pharmaceutical dosage form. J Chil Chem Soc. 2011; 56(2):702-5.

15. Madhavi A, Reddy GS, Suryanarayana MV, Naidu A. Development of a new analytical method for determination of related components in nateglinide. Chromatographia. 2008 Apr $1 ; 67(7-8): 639-45$.

16. Janzen H. Forced Degradation Studies-Comparison between ICH, EMA, FDA and WHO Guidelines and ANVISA's Resolution RDC 53/2015. Master of Drug Regulatory Affairs, Rheinische Friedrich-Wilhelms-University of Bonn, Bonn. 2016.

17. Venkataraman S, Manasa M. Forced degradation studies: Regulatory guidance, characterization of drugs, and their degradation products-a review. Drug Invention Today. 2018 Feb $1 ; 10(2)$.

18. Venkataraman S, Manasa M. Forced degradation studies: Regulatory guidance, characterization of drugs, and their degradation products-a review. Drug Invention Today. $2018 \mathrm{Feb}$ $1 ; 10(2)$.

19. Kaushik D, Bansal G. Characterization of degradation products of idarubicin through LC-UV, MSn and LC-MS-TOF studies. Journal of pharmaceutical and biomedical analysis. 2013 Nov 1;85:123-31.

20. Sahu K, Siddiqui AA, Shaharyar M, Sahu S. Isolation, Identification and Characterization of Degradation Product of Piracetam Using Analytical Techniques. IJARSC. 2014;7:8-16.

Indo Global Journal of Pharmaceutical Sciences( ISSN 2249 1023; CODEN- IGJPAI; NLM ID: 101610675) indexed and abstracted in CrossRef (DOI Enabling), CNKI, UGC CARE Journal List, EMBASE (Elsevier), National Library of Medicine (NLM) Catalog (NCBI), ResearchGate, Publons (Clarivate Analytics), CAS (ACS), Index Copernicus, Google Scholar and many more. For further details, visit http://iglobaljournal.com 